\title{
Stage IV Extrahepatic Bile Duct Cancer
}

National Cancer Institute

\section{Source}

National Cancer Institute. Stage IV Extrahepatic Bile Duct Cancer. NCI Thesaurus. Code C5772.

Stage IV includes: Any T, Any N, M1. M1: Distant metastasis. (AJCC 6th ed.) - 2003 